\title{
Sensitization of Cutaneous Nociceptors after Nerve Transection and Regeneration: Possible Role of Target- Derived Neurotrophic Factor Signaling
}

\author{
Michael P. Jankowski, ${ }^{1}$ Jeffrey J. Lawson, ${ }^{1}$ Sabrina L. McIlwrath, ${ }^{1}$ Kristofer K. Rau, ${ }^{1}$ Collene E. Anderson, ${ }^{1}$ \\ Kathryn M. Albers, ${ }^{2}$ and H. Richard Koerber ${ }^{1}$ \\ Departments of ${ }^{1}$ Neurobiology and ${ }^{2}$ Medicine, University of Pittsburgh School of Medicine, Pittsburgh, Pennsylvania 15261
}

\begin{abstract}
Damage to peripheral nerves is known to contribute to chronic pain states, including mechanical and thermal hyperalgesia and allodynia. It is unknown whether the establishment of these states is attributable to peripheral changes, central modifications, or both. In this study, we used several different approaches to assess the changes in myelinated $(\mathrm{A})$ and unmyelinated $(\mathrm{C})$ cutaneous nociceptors after transection and regeneration of the saphenous nerve. An ex vivo recording preparation was used to examine response characteristics and neurochemical phenotype of different types of functionally defined neurons. We found that myelinated nociceptors had significantly lower mechanical and thermal thresholds after regeneration, whereas C-polymodal nociceptors (CPMs) had lower heat thresholds. There was a significant increase in the percentage of mechanically insensitive $\mathrm{C}$-fibers that responded to heat ( $\mathrm{CHs}$ ) after regeneration. Immunocytochemical analysis of identified afferents revealed that most CPMs were isolectin B4 (IB4) positive and transient receptor potential vanilloid 1 (TRPV1) negative, whereas CHs were always TRPV1 positive and IB4 negative in naive animals (Lawson et al., 2008). However, after regeneration, some identified CPMs and $\mathrm{CHs}$ stained positively for both markers, which was apparently attributable to an increase in the total number of IB4-positive neurons. Real-time PCR analysis of L2/L3 DRGs and hairy hindpaw skin at various times after saphenous nerve axotomy suggested multiple changes in neurotrophic factor signaling that correlated with either denervation or reinnervation of the cutaneous target. These changes may underlie the functional alterations observed after nerve regeneration and may explain how nerve damage leads to chronic pain conditions.
\end{abstract}

Key words: sensory neurons; regeneration; cutaneous; dorsal root ganglion; DRG; pain; growth factor; reinnervation

\section{Introduction}

Peripheral nerve transection leads to axon regeneration and subsequent reinnervation of the target tissue if the cut ends of the nerve are closely approximated. Depending on regeneration distance, this process can take several weeks to months (Horch and Lisney, 1981; Carter and Lisney, 1987; Lisney, 1987; Jankowski et al., 2008) and involves a variety of molecular and biophysical changes in sensory neurons (Taniuchi et al., 1986; Terenghi, 1995; Koerber et al., 1994, 1999; Ruocco et al., 2000; Campbell, 2001; Kury et al., 2001; Koerber and Woodbury, 2002; Priestley et al., 2002; Oaklander and Brown, 2004; Obata and Noguchi, 2004; Bennett et al., 2006). For example, peripheral nerve injury is known to induce changes in neuropeptides, G-protein coupled receptors, signal transduction molecules, ion channels, and growth-associated proteins (Bisby and Keen, 1986; Smith and Skene, 1997; Ishikawa et al., 1999; Kim et al., 2001; Decosterd et al., 2002; Xiao et al., 2002; Obata et al., 2003) in the dorsal root ganglia (DRGs). These changes could be attributable to the injury

Received July 23, 2008; revised Dec. 12, 2008; accepted Dec. 16, 2008.

This work was supported by National Institutes of Health Grants NS23725 and NS52848 (H.R.K.).

Correspondence should be addressed to H. Richard Koerber, Department of Neurobiology, University of Pittsburgh School of Medicine, 3500 Terrace Street, Pittsburgh, PA 15261. E-mail: rkoerber@pitt.edu.

DOI:10.1523/JNEUROSCI.3474-08.2009

Copyright $\odot 2009$ Society for Neuroscience $\quad$ 0270-6474/09/291636-12\$15.00/0 itself and/or the altered environment encountered by the regenerating axons at the injury site (Taniuchi et al., 1986; Lee et al., 2001; Campana et al., 2006) and/or in the target tissue. These alterations have been suggested to correlate with other changes in sensory neurons such as increased spontaneous activity (Xie et al., 1995; Djouhri et al., 2006) and/or hyperexcitability (Wall and Devor, 1983; Kajander and Bennett, 1992; Amir et al., 1999; Waxman, 1999), leading to conditions of acute and/or chronic pain.

It has been proposed that neurotrophic factors in particular may play an important role in injury-induced responses of peripheral sensory neurons (Lundborg et al., 1994; Wang et al., 2003). This is supported by additional studies in which we have shown that constitutive overproduction of neurotrophic factors in the skin induced changes in thermal and mechanical sensitivity of specific cutaneous nociceptors, which were correlated with changes in the levels of putative thermal [transient receptor potential vanilloid (TRPV)] and mechanically [acid sensing ion (ASIC)] sensitive ion channels. For example, excess artemin resulted in increased heat sensitivity in C-polymodal nociceptors (CPMs), which was correlated with an increase in TRPV1 (Albers et al., 2006; Elitt et al., 2006). Overexpression of neurotrophin-3 (NT-3) resulted in increased mechanical sensitivity of myelinated nociceptors and was correlated with an increase in the expression of ASIC3 and TRPV2 in DRGs (McIlwrath et al., 2007). Finally, 
we found that cutaneous injection of these and other growth factors can cause acute heat hyperalgesia (Malin et al., 2006).

These results lead us to hypothesize that altered levels of neurotrophic factors in the peripheral target tissues correlate with the changes in regenerating sensory neurons (i.e., hypersensitivity to peripheral stimuli). To test this hypothesis, we used an ex vivo skin/nerve/DRG/spinal cord preparation to quantitatively characterize peripheral response properties of sensory neurons after saphenous nerve axotomy and regeneration. Additionally, we also examined mRNA and protein levels of specific neurotrophic factors in the skin and receptors/channels in DRGs during regeneration to identify molecular changes that correlate with alterations in sensory neuron function.

\section{Materials and Methods}

Animals. Experiments were conducted using age-matched adult (4-6 weeks) male Swiss-Webster (SW) mice (Hilltop Farms). All animals were housed in group cages, maintained in a $12 \mathrm{~h}$ light/dark cycle with a temperature-controlled environment, and given food and water ad libitum. All procedures used in these experiments were reviewed and approved by the Institutional Animal Care and Use Committee at the University of Pittsburgh. Animals were cared for and used in accordance with guidelines of the United States Public Health Service Policy on Humane Care and Use of Laboratory Animals and the National Institutes of Health Guide for the Care and Use of Laboratory Animals and following institutional Association for Assessment and Accreditation of Laboratory Animal Care-approved practices.

Saphenous nerve axotomy. Mice were anesthetized by an injection of a mixture of ketamine and xylazine (90 and $10 \mathrm{mg} / \mathrm{kg}$, respectively). A small incision was made in the skin at the midthigh level over the saphenous nerve. The exposed nerve was transected using fine iridectomy scissors without disturbing the surrounding connective tissue. Therefore, the cut ends of the nerve remained closely apposed. The wound was closed using 7.0 silk sutures. Animals were allowed to survive for 7-84 d after nerve injury for immunocytochemical, electrophysiological, Western blotting, and/or real-time PCR analysis.

Ex vivo preparation. The ex vivo somatosensory system preparation has been described in detail previously (Woodbury et al., 2001). Briefly, mice were anesthetized via injection of ketamine and xylazine (90 and 10 $\mathrm{mg} / \mathrm{kg}$, respectively) and perfused transcardially with oxygenated (95\% $\mathrm{O}_{2}-5 \% \mathrm{CO}_{2}$ ) artificial CSF (aCSF) (in mM: $1.9 \mathrm{KCl}, 1.2 \mathrm{KH}_{2} \mathrm{PO}_{4}, 1.3$ $\mathrm{MgSO}_{4} 2.4 \mathrm{CaCl}_{2}, 26.0 \mathrm{NaHCO}_{3}$, and $10.0 \mathrm{~d}^{\text {-glucose) containing } 253.9}$ $\mathrm{mm}$ sucrose at $12-15^{\circ} \mathrm{C}$. The spinal cord and the right hindlimb were excised and placed in a bath of aCSF. Hairy skin of the right hindpaw, saphenous nerve, DRGs, and spinal cord were isolated. After dissection, the preparation was transferred to a separate recording chamber containing chilled oxygenated aCSF in which the sucrose was replaced with 127.0 $\mathrm{mm} \mathrm{NaCl}$. The skin was pinned out on a stainless steel grid located at the bath/air interface, such that the dermal surface remained perfused with the aCSF while the epidermis stayed dry. The platform served to provide stability during applied thermal and mechanical stimuli. The bath was then slowly warmed to $31^{\circ} \mathrm{C}$ before recording.

Recording and stimulation. Sensory neuron somata were impaled with quartz microelectrodes (impedance $>150 \mathrm{M} \Omega$ ) containing 5\% Neurobiotin (Vector Laboratories) in $1 \mathrm{~m}$ potassium acetate. Orthograde electrical search stimuli were delivered through a suction electrode on the nerve to locate sensory neuron somata innervating the skin. Peripheral receptive fields (RFs) were localized with a blunt glass stylus and von Frey hairs. When cells were driven by the nerve but had no mechanical RF, a thermal search was conducted. This was accomplished by applying hot $\left(\sim 52^{\circ} \mathrm{C}\right)$ and/or cold $\left(\sim 0^{\circ} \mathrm{C}\right)$ physiological saline to the skin. There was some concern that the brief but multiple applications of hot saline might cause sensitization of nociceptors during the course of an experiment. We examined this possibility in a recent study (Lawson et al., 2008) and found no change in average heat thresholds obtained at the onset of the experiment when compared with the average heat thresholds of the last fibers recorded. We have made a similar comparison of the data from these experiments in mice after nerve regeneration and also found no change in the average heat thresholds during the course of these experiments (data not shown).

The response characteristics of DRG cells were determined by applying digitally controlled mechanical and thermal stimuli. The mechanical stimulator consisted of a tension/length controller (Aurora Scientific) attached to a 1-mm-diameter plastic disc. Computer-controlled $5 \mathrm{~s}$ square waves of $1,5,10,25,50$, and $100 \mathrm{mN}$ were applied to the $\mathrm{RF}$ of the cell. After mechanical stimulation, a controlled thermal stimulus was applied using a $3 \mathrm{~mm}^{2}$ contact area peltier element (Yale University Machine Shop). The temperature stimulus consisted of a $12 \mathrm{~s}$ heat ramp from 31 to $52^{\circ} \mathrm{C}$, followed by a $5 \mathrm{~s}$ plateau at $52^{\circ} \mathrm{C}$. The stimulus then ramped back down to $31^{\circ} \mathrm{C}$ in $12 \mathrm{~s}$. Adequate recovery times $(\sim 30 \mathrm{~s})$ were used between stimulations. While recording from myelinated nociceptors in many cases, multiple heat applications were made, and, in some cases, the heat ramp was continued to $54^{\circ} \mathrm{C}$ and held for $5 \mathrm{~s}$. In other instances, fibers that were unable to be characterized by computercontrolled mechanical or thermal stimulation but were characterized by von Frey and/or saline stimuli were not included in the determination of thresholds. All elicited responses were recorded digitally for offline analysis (Spike2 software; Cambridge Electronic Design). After physiological characterization, select cells were labeled by iontophoretic injection of Neurobiotin (two to three cells per DRG). Peripheral conduction velocity $(\mathrm{CV})$ was then calculated from spike latency and the distance between stimulating and recording electrodes (measured directly along the nerve). All electrophysiological and immunocytochemical experiments in naive and nerve-injured mice were performed blinded to the experimenter.

Tissue processing and analysis of recorded cells. Once a sensory neuron was characterized and intracellularly filled with Neurobiotin, the DRG containing the injected cell was removed and immersion fixed with $4 \%$ paraformaldehyde in $0.1 \mathrm{M}$ phosphate buffer $(\mathrm{PB})$ for $30 \mathrm{~min}$ at $4^{\circ} \mathrm{C}$. Ganglia were then embedded in $10 \%$ gelatin, postfixed in $4 \%$ paraformaldehyde, and cryoprotected in $20 \%$ sucrose. Frozen sections $(60 \mu \mathrm{m})$ were collected in PB and reacted with fluorescently tagged (FITC) avidin to label Neurobiotin-filled cells (Vector Laboratories). Next, each section was processed for isolectin B4 (IB4) binding (AlexaFluor 647; Invitrogen) and/or TRPV1 (1:500; Calbiochem), CGRP (1:2000; Millipore Bioscience Research Reagents), TRPV2 (1:2000; gift from M. Caterina, Johns Hopkins University, Baltimore, MD), and ASIC3 (1:1000; Millipore Bioscience Research Reagents) immunohistochemistry. After incubation in primary antiserum, tissue was washed and incubated in cyanine 3 (Сy3)conjugated donkey anti-rabbit secondary antiserum (1:200; Jackson ImmunoResearch). Distribution of fluorescent staining was determined using Olympus FluoView 500 laser-scanning confocal microscope. Sequential scanning was performed to prevent bleed through of the different fluorophores.

The coexpression of IB4 and TRPV1 was analyzed in four L3 DRGs from naive mice and three L3 DRGs from each nerve injured group. DRGs were taken after electrophysiological experiments and stained as described above. Tissue sections were analyzed as reported previously (Christianson et al., 2006). In brief, three nonconsecutive sections were randomly chosen, and $15 \mu \mathrm{m}$ stacks with $3-\mu \mathrm{m}$-thick optical sections were captured using a $40 \times$ oil-immersion objective. Multiple optical stacks were taken of each selected tissue section, and visual confirmation was used to avoid analyzing cells twice. The number of IB4- and TRPV1positive cells and those immunoreactive for both proteins were counted and averaged in the top and bottom optical section of each stack. The percentage of double-labeled cells was determined and reported as mean \pm SEM.

Sections of hairy hindpaw skin from naive and nerve-injured mice were also dissected, fixed, and sectioned as described. Skin sections were blocked and incubated in primary antiserum rabbit anti-PGP9.5 (1:500; Ultraclone) overnight at room temperature. After incubation in primary antiserum, tissue was washed and incubated in Cy3-conjugated goat anti-rabbit secondary antiserum (1:200; Jackson ImmunoResearch). Tissue was analyzed as described above using confocal microscopy.

RNA isolation and real-time PCR. Animals were anesthetized as described, and the dorsal hindpaw skin was shaved. The skin innervated by 
the saphenous nerve was quickly removed, taking care to acquire skin from the central part of the innervation field. Trizol reagent was then used to isolate RNA from skin. The mice were then intracardially perfused with ice-cold $0.9 \% \mathrm{NaCl}$ before dissection of DRGs. RNA isolation from the L2 and L3 DRGs was performed using Qiagen RNeasy mini kits for animal tissues using the supplied protocol. RNA concentrations were then determined by obtaining A260 readings on a GeneQuant spectrometer. Purified RNA was treated with DNase I (Invitrogen) for $15 \mathrm{~min}$ at room temperature, and $1 \mu \mathrm{g}$ of DNased RNA was reverse transcribed using Superscript II Reverse Transcriptase (Invitrogen). For real-time PCR, 20 ng samples of cDNA were added to a SYBR Green MasterMix (Applied Biosystems) and run in triplicate on an Applied Biosystems Imager. Values were normalized to glyceraldehyde-3-phosphate dehydrogenase (GAPDH), and changes in expression were calculated as a $\Delta \Delta \mathrm{Ct}$ value that is determined by subtracting the cycle time $(\mathrm{Ct})$ values of the gene of interest from the GAPDH internal control for each sample and compared among samples. Fold change is described as $2^{\Delta \Delta \mathrm{Ct}}$ (Applied Biosystems), and twofold change equals $100 \%$ change. GAPDH did not change after axotomy in any samples relative to naive mice and verified the use of this internal control for normalization.

Primer sequences. Forward and reverse primer sequences used in realtime PCR reactions for GFR $\alpha 3$, tyrosine receptor kinase A (trkA), TRPV1, TRPV2, TRPV3, TRPV4, ASIC1, ASIC2a, ASIC3, and GAPDH were obtained from Elitt et al. (2006). All remaining sequences are as follows: nerve growth factor (NGF): forward, $5^{\prime}$-ACA CTC TGA TCA CTG CGT TTT TG-3'; reverse, 5' -CCT TCT GGG ACA TTG CTA TCT GT-3'; BDNF: forward, 5' -CCA TAA GGA CGC GGA CTT GT-3'; reverse, $5^{\prime}$-AGG AGG CTC CAA AGG CAC TT-3'; NT-3: forward, 5' -CCT GTG GGT GAC CGA CAA G-3'; reverse, 5'-GAT CTC CCC CAG CAC TGT GA-3'; NT-4/5: forward, 5' -GGA GGC ACT GGC TCT CAG AAT3'; reverse, 5'-CCC TGG GAG TCT GCA GTC AA-3'; glial cell linederived neurotrophic factor (GDNF): forward, $5^{\prime}$-AGC TGC CAG CCC AGA GAA TT-3'; reverse, 5'-GCA CCC CCG ATT TTT GC-3'; Neurturin: forward, 5' -TGA GGA CGA GGT GTC CTT CCT-3'; reverse, 5'-AGC TCT TGC AGC GTG TGG TA-3'; artemin: forward, 5'-GGC CAA CCC TAG CTG TTC T- $3^{\prime}$; reverse, 5' -TGG GTC CAG GGA AGC TT-3'; p75: forward, 5'-GGG TGA TGG CAA CCT CTA CAG T-3'; reverse, 5'-GTG TCA CCA TTG AGC AGC TTC T-3'; trkB: forward, 5'-GCT GAT GGC AGA GGG TAA CC-3'; reverse, 5'-GCG ATT TGC TGA GCG ATG T-3'; trkC: forward, 5'-GCT TTC CAA CAC GGA GGT CAT- $3^{\prime}$; reverse, $5^{\prime}$-GCA GAC TCT GGG TCT CTC CAA- $3^{\prime}$; GFR $\alpha 1$ : forward, $5^{\prime}$-GTG TGC AGA TGC TGT GGA CTA G-3'; reverse, $5^{\prime}$-TTC AGT GCT TCA CAC GCA CTT G-3'; GFR $\alpha 2$ : forward, 5' -TGA CGG AGG GTG AGG AGT TCT-3'; reverse, 5' -GAG AGG CGG GAG GTC ACA G-3'; P2X3: forward, 5' -TGG AGA ATG GCA GCG AGT A-3'; reverse, 5' -ACC AGC ACA TCA AAG CGG A-3'; P2Y1: forward, 5' GGC TAT CTG GAT GTT CGT TTT CC-3'; reverse, $5^{\prime}$-CCA GAG CCA AAT TGA ACA TGT ACA-3'; P2Y2: forward, 5' -TTG GCA GGG GCT CAG GA-3'; reverse, 5'-GCA TAG GAG TCG GGT GCA-3'.

Western blot. Hairy hindpaw skin or DRGs from nerve-injured mice was homogenized in lysis buffer containing $1 \%$ SDS, $10 \mathrm{~mm}$ Tris- $\mathrm{HCl}$, $\mathrm{pH} 7.4$, and protease inhibitors $(1 \mu \mathrm{g} / \mathrm{ml}$ pepstatin, $1 \mu \mathrm{g} / \mathrm{ml}$ leupeptin, 1 $\mu \mathrm{g} / \mathrm{ml}$ aprotinin, $1 \mathrm{~mm}$ sodium orthovanadate, and $100 \mu \mathrm{g} / \mathrm{ml}$ phenylmethylsulfonyl fluoride; Sigma). Samples $(10 \mu \mathrm{g})$ were centrifuged, boiled $10 \mathrm{~min}$ in a denaturing buffer containing $\beta$-mercaptoethanol and SDS, separated on an $8 \%$ (artemin) or $15 \%($ GFR $\alpha 3)$ polyacrylamide SDS-PAGE gel, and transferred to a polyvinylidene difluoride (Hybond) membrane (GE Healthcare) that was blocked in 5\% milk (in $0.1 \mathrm{M}$ Trisbuffered saline with $0.1 \%$ Tween 20 ) and then incubated with primary antibodies overnight at $4^{\circ} \mathrm{C}$ [GFR $\alpha 3,1: 100$ (R \& D Systems); artemin, 1:500 (R \& D Systems); actin, 1:10,000 (Sigma)]. Antibody binding was visualized using horseradish peroxidase-conjugated goat anti-rabbit or donkey anti-goat secondary antibodies $(1: 10,000)$ and chemiluminescence detection (Pierce). Immunoreactive bands were analyzed by densitometry and intensity quantified using NIH ImageJ software. Band intensity was normalized to actin and reported as a percentage change.

Data analysis. One-way ANOVA tests and post hoc analysis (Tukey's tests) were used to analyze differences in firing rate and instantaneous frequency in low-threshold mechanoreceptors. Nonparametric,
Kruskal-Wallis tests and post hoc analysis (Dunn's test) were used to analyze data associated with mechanical and thermal thresholds of both myelinated (A) and unmyelinated (C) fibers. This information was sorted by neuronal functional type to examine whether or not certain classes of neurons have coherence with regard to the expression of any of the markers tested. Differences in fiber prevalence were determined by $\chi^{2}$ analysis. Percentage changes in mRNA were also determined to be statistically significant by ANOVA with post hoc analysis (Tukey's). Statistical analyses were performed on the raw $\mathrm{Ct}$ data and represented for ease of presentation as a percentage change. $p$ values were set at $p<0.05$.

\section{Results}

\section{Time course of denervation and reinnervation of skin by} axotomized and regenerating saphenous axons

The time course of denervation and reinnervation of the hairy hindpaw skin by the axotomized and regenerating saphenous nerve was determined by immunolabeling the skin with panaxonal marker PGP9.5 (Fig. 1). Seven days after saphenous nerve axotomy, the skin is virtually devoid of all axonal innervation (Fig. 1A). After $14 \mathrm{~d}$, the dermis began to be reinnervated by regenerating saphenous afferents (Fig. $1 B$ ), and, after $21 \mathrm{~d}$, the epidermis was reinnervated (Fig. 1C). After 4 weeks, both the epidermis and dermis were heavily reinnervated by putative regenerated afferent fibers (Fig. 1D), although the extent of reinnervation did not appear to completely reach that of control mice at this time point (Fig. 1E). We did not observe any obvious qualitative differences between proximal and distal portions of the cutaneous target at any of the time points tested (data not shown). It should be noted that, using this histochemical approach, we are unable to determine the difference between regenerated fibers and possible collateral sprouts of intact fibers. To minimize this possibility, we have sampled areas of skin well within the borders of the saphenous nerve innervation field. Regardless, our subsequent recording experiments verified that ample reinnervation by regenerated saphenous nerve fibers had occurred at the 4-6 week time point.

In addition to these anatomical assessments, mice were also tested behaviorally by pinching the reinnervated skin using small serrated forceps. Foot pinching was performed on the dorsal surface of the hindpaw skin at a point between the ankle and the digits. Whereas this stimulus elicited a withdrawal reflex in some animals as early as 3 weeks after transection, at the 4 week time point, all mice exhibited clear responses to foot pinch. Based on these results, we began functional analysis of single sensory neurons 4 weeks after nerve transection. Given the high probability that additional fibers would be continuing to reinnervate the saphenous skin at this time point, we examined fibers during a 2 week window after nerve cut ( $4-6$ weeks). To determine whether the functional properties of regenerated fibers were altered with time after regeneration, we also examined mice at 10-12 weeks after axotomy.

\section{Axotomy and regeneration induces changes in the electrophysiological response properties and neurochemical phenotype of DRG neurons}

A total of 309 primary cutaneous neurons were intracellularly recorded and physiologically characterized from 27 naive (187) and 36 (122) nerve injured Swiss-Webster mice. Of these, 14 mice were used for the 4-6 week time point and 22 for the 10-12 week time point. Neurons with a conduction velocity of $<1.2 \mathrm{~m} / \mathrm{s}$ were classified as C-fibers (Kress et al., 1992), and all others were classified as A-fibers. Conduction velocities between 1.2 and $10 \mathrm{~m} / \mathrm{s}$ were considered to be in the A $\delta$ range, and those $\geq 10 \mathrm{~m} / \mathrm{s}$ were classified as conducting in the $\mathrm{A} \beta$ range (Koltzenburg et al., 1997; 

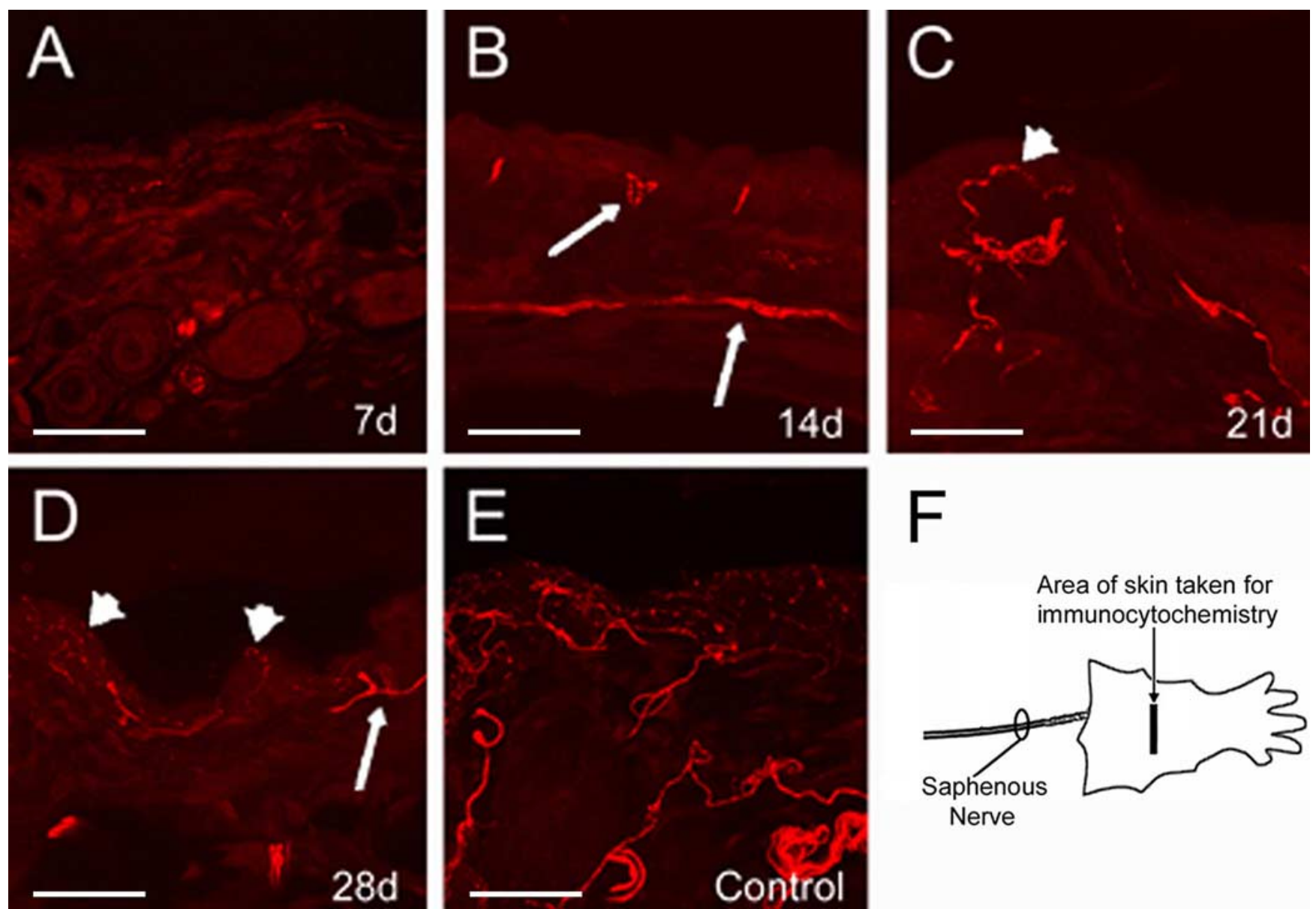

Figure 1. Light micrographs of saphenous nerve innervation area of the skin immunopositive for PGP9.5. Seven days after axotomy of the saphenous nerve, the skin is virtually devoid of neuronal innervation $(\boldsymbol{A})$. Two weeks after injury, the dermis begins to be reinnervated ( $\boldsymbol{B}$; arrows). The epidermis is first reinnervated 3 weeks after injury $(\boldsymbol{C} ;$ arrowhead), whereas, four weeks after nerve transection, the epidermis (arrowheads) and dermis (arrows) are readily reinnervated $(\boldsymbol{D})$. The innervation pattern is not as extensive as uninjured control skin at any of the time points $(\boldsymbol{E})$. Diagram of area of hairy hindpaw skin taken for PGP9.5 immunocytochemistry $(\boldsymbol{F})$. Scale bar, $500 \mu \mathrm{m}$.

McIlwrath et al., 2007). In both naive and nerve-regenerated preparations, we encountered a number of cells that were driven by the electrical nerve stimulus but were found to be both mechanically and thermally unresponsive (data not shown). However, only cells that had a response to cutaneous stimulation (mechanical or thermal) were included in the analysis. Myelinated fibers were divided into two groups, low-threshold mechanoreceptors and high-threshold mechanoreceptors (nociceptors) based on mechanical response properties and somal spike shapes. For example, in addition to clear differences in their peripheral response properties, myelinated nociceptors also had characteristic broad action potentials with inflections on the falling phase of the spike (Koerber et al., 1988). The low-threshold mechanoreceptors were divided into three groups: (1) slowly adapting type 1 (SA1); (2) A $\beta$ rapidly adapting (RA) (guard-hair afferents); and (3) A $\delta$ rapidly adapting down-hair (D-hair) afferents. Naive SA1, $\mathrm{RA}$, and D-hair afferent mechanical thresholds were determined to be $6.1 \pm 1.9 \mathrm{mN}(n=13), 5.1 \pm 0.6 \mathrm{mN}(n=20)$, and $2.9 \pm$ $0.8 \mathrm{mN}(n=13)$, respectively. A-fiber nociceptors were sorted into two categories: A-polymodal, meaning those that respond to mechanical and thermal stimuli (APM) $(n=18)$, and A-mechanical (AM), meaning those that only responded to this single modality $(n=13)$. In naive mice, $\mathrm{A} \beta$ and $\mathrm{A} \delta$ nociceptors had statistically indistinguishable mechanical and heat thresholds $(23.3 \pm 3.7 \mathrm{mN}, n=6 ; 20.8 \pm 3.0 \mathrm{mN}, n=18$; and $41.5 \pm$ $0.4^{\circ} \mathrm{C}, n=4 ; 41.8 \pm 0.7^{\circ} \mathrm{C}, n=9$, respectively). Therefore, for additional statistical analysis, these fiber types were combined. Collectively, naive A-fiber nociceptors had a mechanical threshold of $21.9 \pm 3.5 \mathrm{mN}(n=24)$ and heat threshold of $41.8 \pm 0.9^{\circ} \mathrm{C}$ $(n=13)$. In five cases, APMs responded to a thermal stimulation (hot saline), but threshold was unable to be obtained.

The C-fiber classes included: (1) C-polymodal (CPM), which responded to mechanical and heat $(\mathrm{CMH})$ and sometimes cool/ cold stimuli (CMHC); (2) C-mechano (CM), which responded only to mechanical deformation of the RF of the cell; (3) C-mechano cool/cold (CMC), which responded to mechanical and cooling (but not heating); (4) C-heat $(\mathrm{CH})$, which were mechanically insensitive but responded to heat stimuli; and (5) Ccooling/cold (CC), which were mechanically insensitive but responded to lowering skin temperature. Of the total $110 \mathrm{C}$-fibers characterized in naive mice, the largest group of cutaneous C-fibers was that classified as polymodal $(61 \% ; n=68)$. The other groups were less prevalent. CMs constituted 17\% $(n=20)$, CMCs $14 \%(n=15)$, CHs $5 \%(n=5)$, and CCs $2 \%(n=2)$ of recorded afferents. Overall, the different $\mathrm{C}$-fiber groups had similar mechanical and thermal thresholds. In naive mice, the average heat threshold for the CPMs was $42.6 \pm 0.5^{\circ} \mathrm{C}$, and, for $\mathrm{CH}$ fibers, it was $41.0 \pm 1.6^{\circ} \mathrm{C}$. The average mechanical thresholds were $20.9 \pm 2.2 \mathrm{mN}$ for CPM fibers, $27.8 \pm 6.2 \mathrm{mN}$ for CM fibers, and $11.4 \pm 5.8 \mathrm{mN}$ for CMC fibers. Although the mechanical 

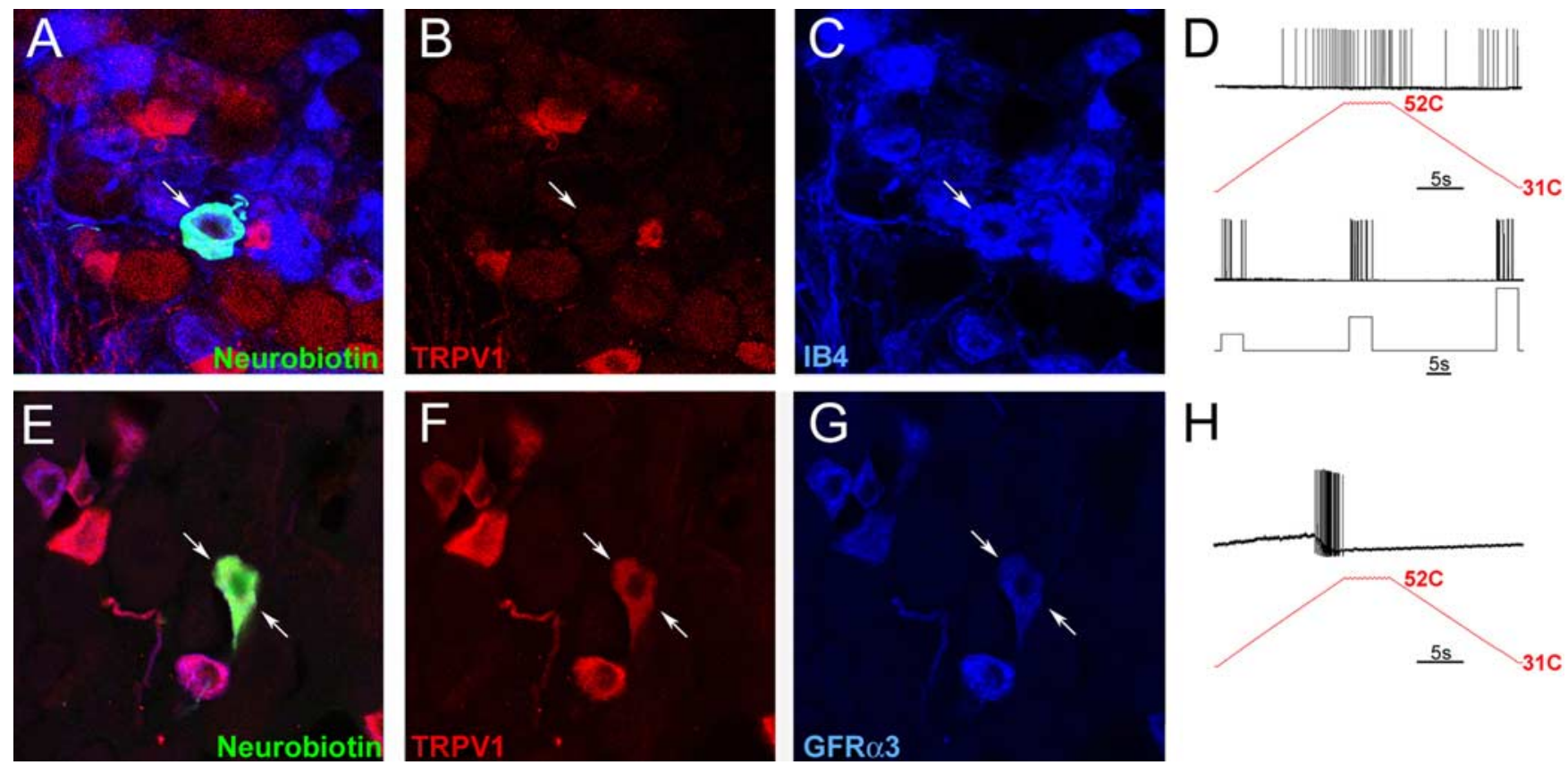

Figure 2. Characterization of the immunocytochemical and electrophysiological response properties of naive CPM and CH fibers in the L2/L3 DRG using the saphenous nerve ex vivo preparation. An example of a cutaneous sensory neuron intracellularly labeled with Neurobiotin ( $\boldsymbol{A}$; arrow) found to be immunonegative for TRPV1 (B; arrow) but positive for IB4 ( $\boldsymbol{C}$; arrow) responded to both mechanical and thermal stimulation (D), classifying it as a (PM. Another case of a Neurobiotin-labeled cell ( $\boldsymbol{E}$; arrows) that was found to be immunopositive for TRPV1 (F; arrows) and GFR $\alpha 3$ ( $\boldsymbol{G}$; arrows). This cell was mechanically insensitive but responded to heat, characterizing it as a $\mathrm{CH}$ fiber $(\boldsymbol{H})$.

thresholds for the CPM fibers were lower on average than for the CM fibers, they were not significantly different $(p=0.1)$. Although the CMC fibers were not statistically different from $\mathrm{CPM}$ fibers, they were different from the CM fibers $(p=0.05)$. However, this finding is somewhat misleading because some fibers in the CMC group had thermal thresholds in the noxious range but had mechanical thresholds that would be considered to be innocuous (i.e., $<5 \mathrm{mN}$ ) (Lawson et al., 2008).

In naive SW mice, 76 cutaneous sensory neurons were intracellularly labeled, recovered, and immunohistochemically characterized. The result of this analysis was in complete agreement with our previous studies (Woodbury et al., 2004; Lawson et al., 2008). For example, we found that 17 of 26 CPM fibers $(65 \%)$ bound IB4, whereas none stained positively for TRPV1 (0 of 18) (Fig. 2, Table 1). In addition, many myelinated nociceptors were found to contain ASIC3 (5 of 6) and/or TRPV2 (6 of 14) (McIlwrath et al., 2007; Lawson et al., 2008). Fifty percent of CM fibers ( $n=2$ of 4 ) also bound IB4, and none were found to be TRPV1 positive. Four cells characterized as mechanically insensitive, and heat-sensitive $\mathrm{CH}$ fibers did not bind IB4 (data not shown) but all were immunopositive for TRPV1 (Table 1). These $\mathrm{CH}$ neurons were also found to be immunoreactive for GFR $\alpha 3$ (Fig. 2), although this was only determined for two of the $\mathrm{CH}$ fibers. The finding that positive TRPV1 staining and IB4 binding were found in functionally different subsets of cutaneous C-fibers is in agreement with previous studies showing a lack of colocalization of these markers in mice in general (Zwick et al., 2002) and specifically in $\mathrm{CH}$ fibers (Lawson et al., 2008). All CMC fibers were found to be IB4 negative.

\section{Regenerated A-fibers}

Examination of the response properties $4-6$ weeks after axotomy and successful regeneration demonstrated that A-fiber nociceptors had a significant reduction in their mechanical thresholds $(7.8 \pm 2.9$ vs $21.9 \pm 3.5 \mathrm{mN} ; p<0.02$, Kruskal-Wallis and
Table 1. Immunostaining results for naive Swiss-Webster A and C cutaneous neurons

\begin{tabular}{llllll}
\hline Neuron type & IB4 $^{+}$ & TRPV1 $^{+}$ & CGRP $^{+}$ & TRPV2 $^{+}$ & ASIC3 $^{+}$ \\
\hline AM & nt & 0 of 1 & 1 of 1 & 3 of 5 & 4 of 5 \\
APM & 1 of 2 & 1 of 8 & 0 of 3 & 2 of 8 & nt \\
AMC & nt & nt & nt & 1 of 1 & 1 of 1 \\
CH & 0 of 4 & 4 of 4 & nt & nt & nt \\
CM & 2 of 4 & 0 of 5 & 1 of 2 & 0 of 2 & $n t$ \\
CMC & 0 of 4 & 0 of 1 & 2 of 2 & 1 of 3 & nt \\
CPM & 17 of 26 & 0 of 18 & 2 of 7 & 1 of 4 & 0 of 1 \\
\hline
\end{tabular}

Quantification of the percentage of IB4 binding and TRPV1-, CGRP-, and ASIC3-immunoreactive neurons intracellularly labeled with Neurobiotin in the ex vivo preparation in uninjured mice. nt, Not tested.

Table 2. Immunostaining results for Swiss-Webster A and C cutaneous neurons after saphenous nerve cut

\begin{tabular}{llllll}
\hline Neuron type & IB4 $^{+}$ & TRPV1 $^{+}$ & CGRP $^{+}$ & TRPV2 $^{+}$ & ASIC3 $^{+}$ \\
\hline AM & 0 of 1 & 0 of 1 & 0 of 3 & 5 of 9 & nt \\
APM & 0 of 1 & 0 of 1 & 1 of 6 & 3 of 7 & $n t$ \\
AMC & nt & nt & nt & nt & nt \\
CH & 5 of 9 & 8 of 8 & nt & 0 of 1 & $n t$ \\
CM & 2 of 3 & 0 of 3 & nt & nt & $n t$ \\
CMC & 0 of 1 & 0 of 1 & nt & nt & $n t$ \\
CPM & 15 of 19 & 3 of 19 & nt & nt & nt \\
\hline
\end{tabular}

Quantification of the percentage of IB4 binding and TRPV1-, CGRP-, and ASIC3-immunoreactive neurons intracellularly labeled with Neurobiotin in the ex vivo preparation in saphenous nerve-axotomized mice. nt, Not tested.

Dunn's post hoc analysis). Thermal thresholds were also found to be significantly decreased at this time point ( $37.4 \pm 1.0$ vs $41.7 \pm$ $0.9^{\circ} \mathrm{C} ; p=0.02$ ) relative to naive controls (Fig. 3). After 10-12 weeks of recovery from saphenous nerve axotomy, the decrease in mechanical thresholds was no longer significant $(23.6 \pm 5.3$ $\mathrm{mN}$ ); however, thermal thresholds of A-fiber nociceptors remained significantly decreased $\left(37.5 \pm 0.6^{\circ} \mathrm{C} ; p=0.02\right)$. Although myelinated low-threshold mechanoreceptors did not show statistically different mechanical thresholds, there were sig- 

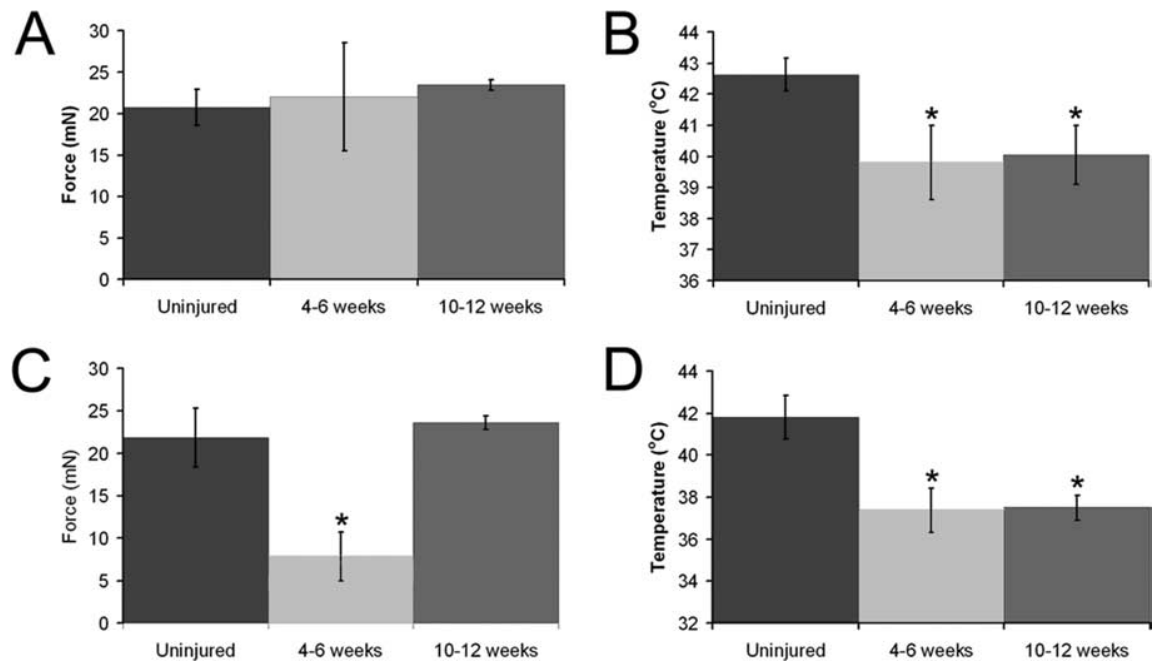

Figure 3. Electrophysiological response properties of DRG neurons before and after axotomy of the saphenous nerve in the skin-nerve DRG-spinal cord ex vivo preparation. Polymodal C-fibers did not show any change in mechanical threshold after regeneration ( $4-6$ weeks, $n=18 ; 10-12$ weeks, $n=13)$ relative to uninjured $(n=66)$ neurons $(A)$; however, $4-6$ weeks $(n=$ $19)$ and $10-12$ weeks $(n=18)$ after injury, there was a significant reduction in the thermal thresholds of these neurons compared with naive $(n=60)$ mice $(\boldsymbol{B})$. A-fiber nociceptors showed a decrease in both their mechanical (naive, $n=24 ; 4-6$ weeks, $n=$ 7; $10-12$ weeks, $n=26 ; \boldsymbol{C}$ ) and thermal (naive, $n=12 ; 4-6$ weeks, $n=4 ; 10-12$ weeks, $n=10 ; \boldsymbol{D}$ ) thresholds after saphenous nerve axotomy. Mechanical threshold returned to baseline, however, 10-12 weeks after injury in these fibers, whereas thermal threshold remained significantly lower. ${ }^{*} p<0.02$.
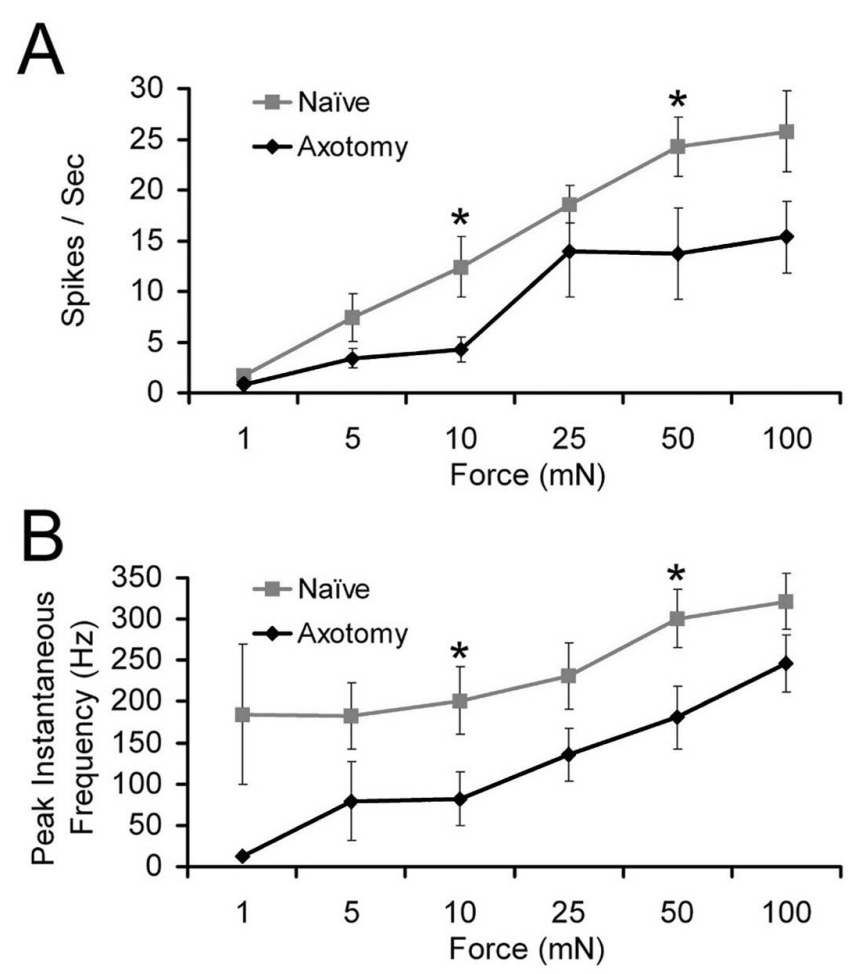

Figure 4. Firing rates and instantaneous frequencies of SA1 neurons to mechanical stimulation before and after regeneration of the saphenous nerve. $A$, The number of spikes per second at 10 and $50 \mathrm{mN}$ forces in SA1 fibers is significantly reduced after axotomy and regeneration (black) compared with naive mice (gray). $\boldsymbol{B}$, The instantaneous frequency of SA1 fibers is also reduced during 10 and $50 \mathrm{mN}$ mechanical stimulations after nerve transection and regeneration (black) relative to uninjured controls (gray). At $10 \mathrm{mN}$, naive, $n=11$; regeneration, $n=8$. At $50 \mathrm{mN}$, naive, $n=13$; regeneration, $n=11 .{ }^{*} p<0.05$. nificant differences in the mean firing rates and peak instantaneous frequencies of SA1 fibers to higher intensities of mechanical stimuli when compared with naive mice $(p<0.05$, ANOVA and post hoc analysis) (Fig. 4). This suggests that, after reinnervation, SA1 fiber function does not completely return to prelesion levels.

\section{Regenerated C-fibers}

Shortly after functional reinnervation of the cutaneous target (4-6 weeks), CPM thermal thresholds were significantly reduced to $39.8 \pm 1.2^{\circ} \mathrm{C}(p=0.02)$ (Fig. 3 ); however, mechanical thresholds were not significantly different at this time point $(22.0 \pm 6.0 \mathrm{mN} ; p=0.9)$. At $10-12$ weeks after saphenous nerve axotomy and regeneration, CPMs still showed a significant decrease in thermal threshold $\left(40.1^{\circ} \mathrm{C} \pm\right.$ $0.9 ; p=0.02$ ), whereas mechanical threshold remained similar to naive values $(23.2 \pm 2.4 \mathrm{mN} ; p=0.9)$. CM fibers showed no difference in mechanical threshold 10-12 weeks after regeneration $(13.2 \pm 5.0 \mathrm{mN} ; p=0.2$; only one $\mathrm{CM}$ fiber was recovered from the 4-6 week time point). $\mathrm{CH}$ fibers also showed no change in thermal threshold $\left(42.4 \pm 2.6^{\circ} \mathrm{C}, p=0.7\right.$ at $4-6$ weeks; $45.7 \pm 1.9, p=0.2$ at $10-12$ weeks) at any time points tested after axotomy. Interestingly, the prevalence of $\mathrm{CH}$ fibers significantly increased after regeneration ( $p=0.001$ ) (Fig. 5). At 4-6 weeks after nerve cut, $19 \%$ of all recorded C-fibers were found to be mechanically insensitive $\mathrm{CH}$ neurons, and, by 10-12 weeks, this percentage rose to $27 \%$. This increase in $\mathrm{CH}$ fibers was coupled with a decrease in the percentage of CMC and CM fibers (Fig. 5).

\section{Immunostaining of identified cutaneous fibers}

We have examined the neurochemical phenotype of 76 cutaneous sensory neurons from naive mice and 53 regenerated fibers from lesioned mice. Because the results were similar between the 4-6 week groups and the 10-12 week survival groups, they have been combined for ease of presentation. In naive mice, we recovered 38 functionally characterized C-fibers. We found that most CPM fibers stained positively for IB4 (17 of 26), and all were TRPV1 negative ( 0 of 18 ) (Fig. 2, Tables 1,2$)$. These findings are consistent with our previous findings (Lawson et al., 2008). The only other group to bind IB4 was the CMs, in which 50\% (2 of 4) were positive. The only fibers to stain positively for TRPV1 were the mechanically insensitive $\mathrm{CH}$ fibers (4 of 4), whereas calcitonin gene-related peptide (CGRP) was found in some CM, CMC, and CPM fibers. Given the high degree of overlap between TRPV1 and CGRP (Funakoshi et al., 2006; Price and Flores, 2007), most of the CH fibers would also contain CGRP. For the myelinated fiber group, we only examined those classified as nociceptive fibers. We found that many of these fibers stained positively for TRPV2 (6 of 14), and most were positive for ASIC3 (5 of 6), which is in agreement with our previous findings (McIlwrath et al., 2007; Lawson et al., 2008).

After regeneration, all eight $\mathrm{CH}$ fibers were found to be TRPV1 positive; however, five of nine examined were also found to bind IB4 (Fig. 6, Tables 1, 2). In addition, we found that some 
of the CPM fibers were IB4 and TRPV1 positive ( 3 of 19) after regeneration. Based on the results presented in the current study, these differences in staining did not reach statistical significance, However, in our previous publication (Lawson et al., 2008), we found that none of the $\mathrm{CH}$ fibers bound IB4 (0 of 11), and none of the CPM fibers stained positively for TRPV1 (0 of 62 ). Given these previous results, this altered staining is a significant departure from that seen in naive mice. CM fibers were also found to bind IB4 (2 of 3 ) after axotomy as in naive mice, but none of these were immunoreactive for TRPV1.

To determine whether de novo expression of TRPV1 or IB4 binding may have been responsible for changes in neurochemical phenotype of DRG neurons after regeneration, we quantified the percentage of double-labeled IB4 and TRPV1 neurons in the DRGs after axotomy. In naive SW mice, $10.1 \pm 1.1 \%$ of IB4 positive neurons in the L2 and L3 DRGs colabeled for TRPV1, and $11.1 \pm 1.5 \%$ of TRPV1 immunopositive cells bound IB4. At 4-6 weeks after axotomy and regeneration, there was a significant increase in overlap because $22.0 \pm 4.2 \%$ of IB4 neurons were immunopositive for TRPV1, whereas $35.0 \pm 8.2 \%$ of TRPV1 cells were IB4 positive. The findings after 10-12 weeks were similar because $20.7 \pm 2.5 \%$ of IB4 neurons were TRPV1 positive and $34.2 \pm$ $2.6 \%$ of TRPV 1 immunolabeled neurons were IB4 positive (Fig. $6 I, J)$. The number of TRPV1-positive neurons was not altered at either time point after axotomy and regeneration (17.8 \pm 0.9 , naive; $16.3 \pm 0.7,4-6$ weeks; $14.5 \pm 1.9,10-12$ weeks). Conversely, the average number of IB4-positive neurons was increased from $19.4 \pm 1.5$ to $24.7 \pm 1.4$ at $4-6$ weeks and to $24.0 \pm$ 2.0 at $10-12$ weeks. These findings suggest that the increase in overlap in TRPV1 and IB4 labeling is attributable to an increase in the numbers of cells binding IB4 and not to de novo expression of TRPV1.

Another interesting finding was that, after regeneration, the CPM fibers were the only C-fiber group that showed a change in $\mathrm{CV}$. This group had a significant decrease in CV (naive, $0.59 \pm$ $0.02 \mathrm{~m} / \mathrm{s}$; regenerated, $0.47 \pm 0.02 ; p<0.001$ ). This raises the possibility that some of the normally slower conducting $\mathrm{CH}$ fibers (naive, $0.39 \pm 0.02 \mathrm{~m} / \mathrm{s}$; regenerated, $0.40 \pm 0.04 \mathrm{~m} / \mathrm{s}$ ) (Lawson et al., 2008) gained mechanical sensitivity after regeneration, moving them into the CPM group and thus reducing the mean CV for this class of afferents.

\section{Saphenous nerve axotomy induces changes in gene expression in the cutaneous target and DRGs}

We next investigated the possibility that changes in gene expression in the skin and/or DRGs could play a role in the changes in sensory neuron response properties after axotomy and regeneration. We analyzed changes in gene expression using real-time PCR and/or Western blot on the hairy hindpaw skin and L2/L3 DRGs of mice 7, 14, 21, 28, or $70 \mathrm{~d}$ after transection. Four naive mice and three to four axotomized mice per time point were used for reverse transcription-PCR analysis. At $7 \mathrm{~d}$ after axotomy when the skin was denervated (Fig. $1 A)$, artemin $(131 \pm 32 \%)$, GDNF $(54 \pm 15 \%)$ (Fig. 7A), NT-4/5 (102 $\pm 10 \%)$, TRPV3 (77 \pm $16 \%)$, and TRPV4 $(140 \pm 16 \%)$ were detected. Artemin, GDNF, and TRPV4, but not NT-4/5 or TRPV3, remained significantly elevated $14 \mathrm{~d}$ after saphenous nerve transection, a time in which the dermal region was beginning to be reinnervated by saphenous nerve fibers (Fig. $1 B$ ). At $21 \mathrm{~d}$ after nerve cut when the epidermis was first being reinnervated by axons of the saphenous nerve, NGF $(79 \pm 17 \%)$ was significantly increased. Artemin, GDNF, and TRPV4 also remained elevated at this time point. NT-3 levels $(34 \pm 12 \%)$ and BDNF $(47 \pm 10 \%)$ were both elevated at this time point, but these increases did not reach statistical significance (NT-3, $p=0.06$; BDNF, $p=0.08$ ). Four weeks ( $28 \mathrm{~d}$ ) after nerve injury when the cutaneous target is heavily reinnervated, all of the aforementioned neurotrophic factor mRNA levels had returned to baseline. After 10 weeks, only NT-4/5 (50 \pm 9\%) displayed an increase in expression, whereas TRPV3 was decreased $(-90 \pm 23 \%)$. p75 neurotrophin receptor was significantly upregulated from $7 \mathrm{~d}(154 \pm 25 \%)$ to 4 weeks $(98 \pm 12 \%)$. No change in neurturin was detected in the skin after saphenous nerve axotomy at any time tested (Table 3 ).

Corresponding to the changes in neurotrophic factor signaling in the target, artemin receptor GFR $\alpha 3(41 \pm 8 \%)$ (Fig. $7 B$ ), purinoreceptor $\mathrm{P}_{2} \mathrm{X}_{3}(85 \pm 7 \%)$ and ASIC3 $(45 \pm 10 \%)$ were increased in the L2/L3 DRGs during denervation of the skin $7 \mathrm{~d}$ after nerve transection. After $14 \mathrm{~d}$ when the skin was initially being reinnervated, GDNF receptor GFR $\alpha 1$ (102 $\pm 23 \%)$, G-protein-coupled receptors $\mathrm{P}_{2} \mathrm{Y}_{1}(83 \pm 20 \%)$ and $\mathrm{P}_{2} \mathrm{Y}_{2}(151 \pm$ $15 \%)$, and TRPV2 (46 $\pm 16 \%)$ were upregulated. When the epidermis was first experiencing axon reinnervation $21 \mathrm{~d}$ after axotomy, neurturin receptor GFR $\alpha 2(-59 \pm 17 \%)$ was significantly decreased, whereas GFR $\alpha 1(159 \pm 22 \%), \mathrm{P}_{2} \mathrm{X}_{3}(49 \pm 6 \%)$, and $\mathrm{P}_{2} \mathrm{Y}_{2}(255 \pm 13 \%)$ remained significantly elevated. After functional reinnervation of the target ( $28 \mathrm{~d}$ ), TRPV1 (40 $\pm 8 \%$ ) was significantly upregulated, whereas all other genes tested returned to baseline levels. At 10 weeks after axotomy, TRPV1 continued to increase $(87 \pm 21 \%)$ and ASIC2a was significantly increased $(43 \pm 10 \%)$. Trks did not significantly change as a result of axotomy at any time tested with the exception of trkC, which was decreased at 10 weeks $(-84 \pm 11)$. p75, TRPA1, and ASIC1 were also not significantly altered in the DRGs at any time point tested after saphenous nerve injury (Table 4). Western blot analysis verified that changes in mRNA corresponded to changes in protein. Seven days after saphenous nerve axotomy, densitometry analysis determined that there was a $54 \%$ increase in artemin protein in the hairy hindpaw skin (Fig. $7 \mathrm{~A}$, inset) and a $53 \%$ increase in the level of GFR $\alpha 3$ protein in the L2/L3 DRGs (Fig. 7B, inset). 

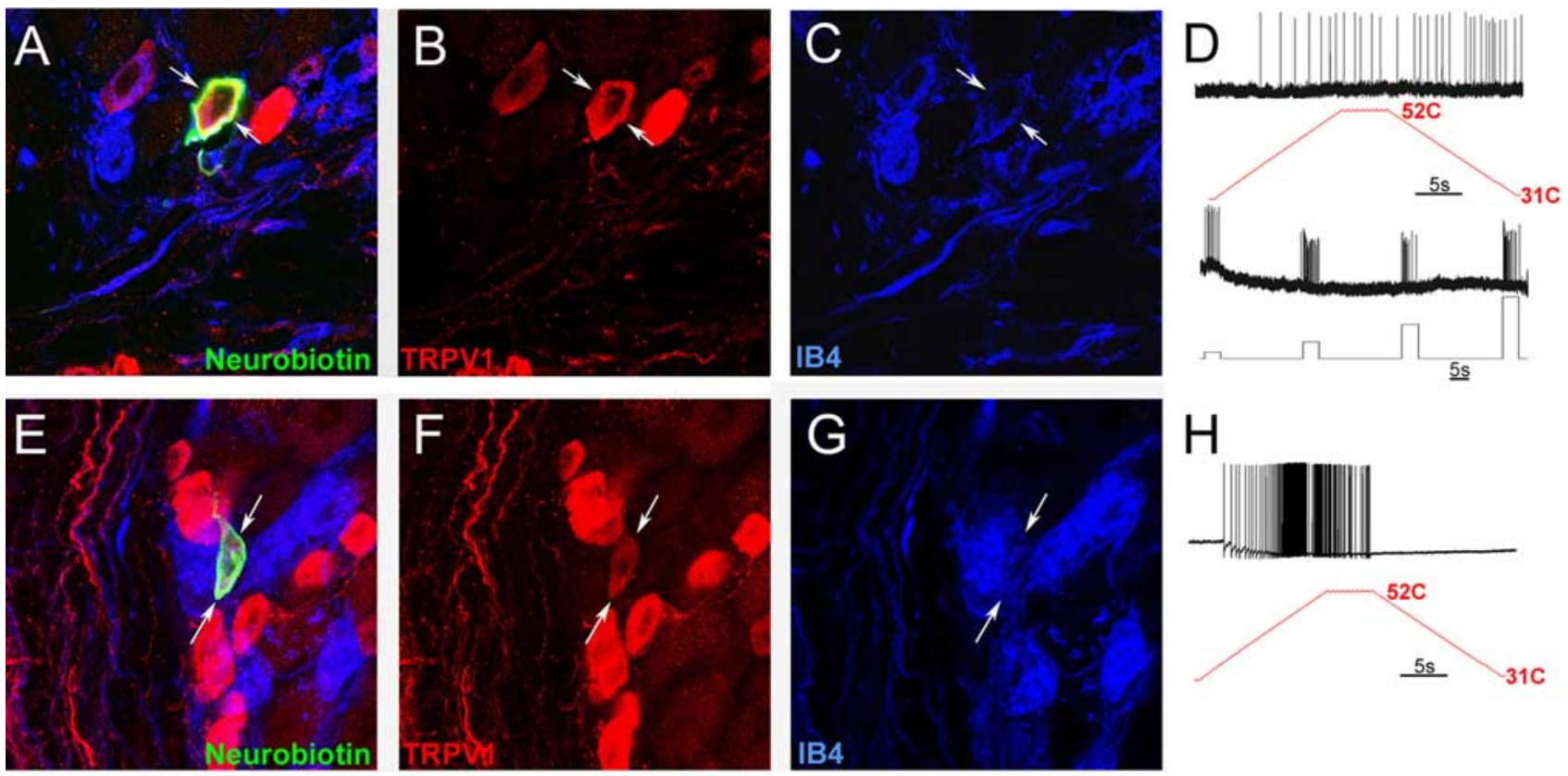
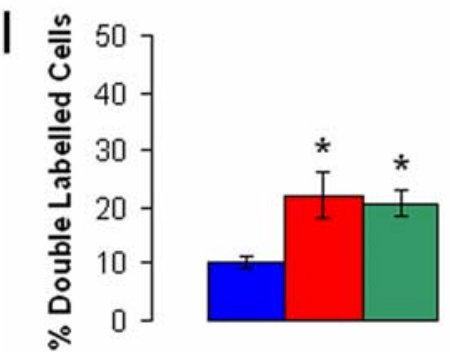

IB4

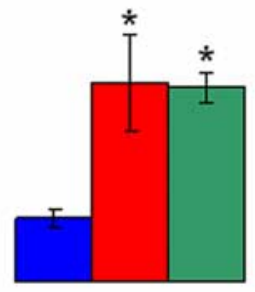

TRPV1

- Uninjured a 4-6 weeks $\square$ 10-12 weeks

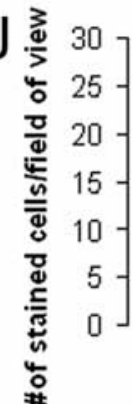

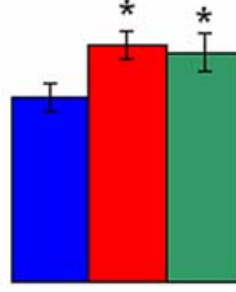

IB4

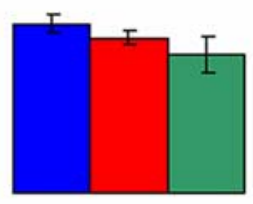

TRPV1
घ Uninjured $\square$ 4-6 weeks $\square$ 10-12 weeks

Figure 6. Characterization of the immunocytochemical and electrophysiological response properties of regenerated C-polymodal (CPM) and C-heat only (CH) fibers in the L2/L3 DRG using the ex vivo preparation. An example of a CPM (D) neuron intracellularly labeled with Neurobiotin 4 weeks after axotomy ( $\boldsymbol{A}$; arrows) was found to be immunopositive for TRPV1 ( $\boldsymbol{B}$; arrows) and positive for IB4 ( $\boldsymbol{C}$; arrows). Another cell characterized as a $\mathrm{CH}(\boldsymbol{H})$ filled with Neurobiotin ( $\boldsymbol{E}$; arrows) was found to be immunopositive for TRPV1 ( $\boldsymbol{F}$; arrows) and positive for IB4 binding ( $\boldsymbol{G}$; arrows). Quantification of TRPV1 immunoreactivity and IB4 binding in uninjured and injured DRGs shows that there is a significant increase in the percentage of cells that double label for both TRPV1 and IB44 - 6 weeks and 10 - 12 weeks after axotomy (I). This was found to be true whether the number of double-labeled cells was quantified as a percentage of IB4 binding or TRPV1 immunoreactivity. Analysis of total IB4 binding and TRPV1 labeling per field of view (see Materials and Methods) suggests that there is an increase only in the number of IB4 neurons after axotomy and regeneration $(J) .{ }^{*} p<0.05$.
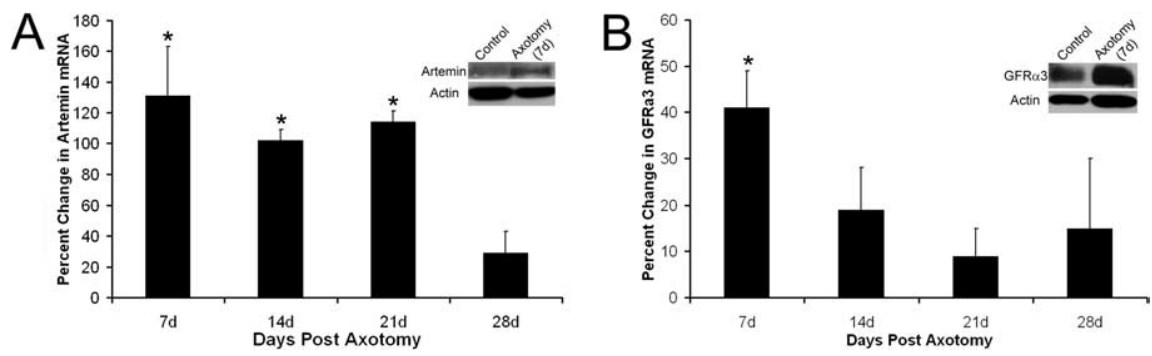

Figure 7. Change in expression of artemin in hairy hindpaw skin and GFR $\alpha 3$ in L2/L3 DRGs at various times after saphenous nerve axotomy. Artemin mRNA is significantly increased in the hairy hindpaw skin $7 \mathrm{~d}(131 \pm 32 \%), 14 \mathrm{~d}(102 \pm 7 \%)$, and $21 \mathrm{~d}$ $(114 \pm 7 \%)$ after saphenous nerve axotomy. mRNA expression returns toward baseline levels by $28 \mathrm{~d}(\boldsymbol{A})$. Western blot analysis verified that an increase in mRNA expression corresponded to an increase in protein expression. Artemin protein was increased $54 \%$ in the cutaneous target of the saphenous nerve $7 \mathrm{~d}$ after axotomy ( $\boldsymbol{A}$, inset). GFR $\alpha 3$ mRNA was also significantly enhanced in the L2/L3 DRGs $7 \mathrm{~d}$ after nerve cut ( $41 \pm 8 \%$ ) but quickly returned to baseline levels by $14 \mathrm{~d}(\boldsymbol{B})$. The change in mRNA was confirmed by Western blot analysis in which a $53 \%$ increase in GFR $\alpha 3$ protein was detected in the L2/L3 DRGs $7 \mathrm{~d}$ after saphenous nerve transection $\left(\boldsymbol{B}\right.$, inset). ${ }^{*} p<0.05$.

\section{Discussion}

Damage to peripheral nerves can lead to mechanical and thermal hyperalgesia and other chronic pain states. Here we have docu- mented after peripheral nerve transection and regeneration that cutaneous nociceptive fibers exhibit increased sensitivity to peripheral stimuli. We also found that changes in cutaneous levels of various neurotrophic factors occurred after denervation and/or during reinnervation by the regenerating saphenous afferents. In addition, these changes were correlated with changes in expression of specific receptors and channels in the appropriate DRGs.

\section{Axotomy and regeneration alters the} response properties of sensory neurons and gene expression in the DRGs and skin

The effects of axotomy and successful regeneration varied among different groups of cutaneous sensory neurons examined. Among myelinated fibers, nociceptors were found to have decreased thermal and mechanical thresholds, whereas SA1 low-threshold mechanorecep- 
tors exhibited normal thresholds but decreased firing rates to mechanical stimuli. The increase in myelinated nociceptor sensitivity coincided with altered expression of NGF in the reinnervated skin and ASIC3 and TRPV2 in the DRGs. In addition, recent data have described mechanical sensitization of myelinated nociceptors in mice that overexpress NT-3 (Mcllwrath et al., 2007). Thus, it should be noted that there was a trend toward increased in NT-3 levels in the skin at $21 \mathrm{~d}(p=0.06)$. Regardless, many myelinated nociceptors do label positively for ASIC3 and/or TRPV2 (McIlwrath et al., 2007; Lawson et al., 2008), and at least some of this increase could be attributable to cells responsive to NGF (Wright and Snider, 1995). The time course of NGF expression in our experiments is different from previous reports describing an increase in NGF within a shorter time frame (Mearow et al., 1993); however, this study axotomizes multiple nerves and samples a larger area of denervation. Because we are only axotomizing a single nerve, it is not unexpected to see a slightly different time course in NGF production.

It should also be noted, however, that changes in expression of ASIC3 and TRPV2 in the DRGs begin before the increased expression of NGF in the skin. This suggests that initiation of these changes does not require alterations in cutaneous levels of neurotrophic factors. The rapid increased expression of these channels in the DRG could be attributable to the injury itself or changes in the neurotrophic factors or other signaling molecules at the injury site (Taniuchi et al., 1986; Lee et al., 2001; Campana et al., 2006; Hoke et al., 2006). Thus, a combination of enhanced signaling through NGF/trkA and the changes in mechanically and thermally sensitive ion channels such as ASIC3 and TRPV2 could lead to the documented changes in A-fiber sensitivity (Table 4) (Tominaga and Caterina, 2004; Bender et al., 2005; Mogil et al., 2005; McIlwrath et al., 2007; Rau et al., 2007; Sluka et al., 2007).

Distinct functional groups of C-fibers were also affected differently after regeneration. CPMs displayed a reduction in thermal threshold with no change in mechanical sensitivity. The majority of these fibers innervating hairy skin bind IB4 and respond to target-derived GDNF (Molliver et al., 1997; Bennett et al., 1998; Leitner et al., 1999; Zwick et al., 2002; Albers et al., 2006). Here we observed that, after nerve injury, GDNF expression is extensively increased in the skin, and its receptor GFR $\alpha 1$ is significantly enhanced in the DRGs (Tables 3 and 4). A recent study has shown that acute cutaneous injection of GDNF can induce thermal hyperalgesia in vivo (Malin et al., 2006). Therefore, it is reasonable to suggest that greater signaling through the GDNF/ GFR $\alpha 1$ pathway could underlie the changes in thermal sensitivity in CPM neurons after axotomy and regeneration. Whereas the heat sensor in these cutaneous nociceptors is unknown, it is clear that it is not TRPV1 because CPM fibers have normal heat sensitivity in TRPV1 ${ }^{-/-}$mice (Woodbury et al., 2004; Lawson et al.,
2008). It will therefore be important in the future to determine whether the observed axotomy-induced changes in levels of other molecules such as purinergic receptors $\mathrm{P}_{2} \mathrm{X}_{3}$ or $\mathrm{P} 2 \mathrm{Y}_{1}$ may play a role in this process, because these receptors are known to colocalize with IB4 in DRG neurons (Bradbury et al., 1998; Ruan and Burnstock, 2003) and have been shown to play a role in neuronal sensitivity (Souslova et al., 2000; Honore et al., 2002; Gerevich et al., 2004; Shimizu et al., 2005). It is also possible that other observed changes in cutaneous expression levels could play a role in the change in heat sensitivity of the CPM fibers. For example, both TRPV3 and TRPV4 expression is increased after denervation of the skin. Both receptors are found in keratinocytes (Chung et al., 2004), and it has been suggested that they could be involved in the release of ATP, which may activate purinergic channels contained in the CPM fibers (Peier et al., 2002; Chung et al., 2003, 2004).

Unlike CPM fibers, $\mathrm{CH}$ fibers that contain TRPV1 (Lawson et al., 2008) do not exhibit sensitization after regeneration. However, there is an apparent recruitment of $\mathrm{CH}$ fibers after regeneration (Fig. 5), suggesting that many $\mathrm{CH}$ fibers are functionally silent under normal conditions but become functional after injury. In support of this possibility, Christianson et al. (2006) showed that $\sim 15-20 \%$ of retrogradely labeled cutaneous C-fibers stained positively for TRPV1, whereas only 5-9\% of functionally characterized cutaneous $\mathrm{C}$-fibers in naive mice were 
$\mathrm{CH}$ neurons (Lawson et al., 2008) (Fig. 5A). Moreover, the increase in the percentage of $\mathrm{CH}$ fibers after regeneration occurs without an increase in the number of TRPV1 cells. This change in function is also correlated with significant increases in expression of artemin and NGF in the skin and GFR $\alpha 3$ and TRPV 1 in the DRGs. Reports have shown that TRPV1 and GFR $\alpha 3$ colocalize extensively in the DRGs (Elitt et al., 2006), and at least some TRPV1-positve CH neurons colabel for GFR $\alpha 3$ (Fig. 2). Other studies also suggest that most TRPV1 neurons are immunoreactive for the NGF receptor trkA (Snider and McMahon, 1998; Orozco et al., 2001; Elitt et al., 2006), both artemin and NGF may regulate TRPV1 expression (Donnerer et al., 2005; Elitt et al., 2006; Xue et al., 2007), and these neurotrophic factors have both been shown to alter heat sensitivity (Malin et al., 2006). Together, these findings suggest that $\mathrm{CH}$ fibers may be sensitive to both artemin and NGF, and altered signaling through these pathways may play a role in the observed recruitment of $\mathrm{CH}$ neurons after axotomy and regeneration. One point to note is that other studies have shown a lack of changes in TRPV1 after injury (Hudson et al., 2001; Fukuoka et al., 2002). However, these studies use different models of nerve injury (spinal nerve ligation or transection without regeneration) and/or do not analyze TRPV1 expression at time points after functional reinnervation of the target tissues, which is when we detect the initial changes in TRPV 1 mRNA in the injured DRGs. Finally, it is important to mention that it is possible that intact fibers also contained within the L2 and L3 DRGs could be contributing to the observed changes in gene expression (Obata et al., 2003). However, evaluation of the possible effects of elevated levels of cutaneous neurotrophic factors on intact fibers is beyond the scope of the present study.

\section{Axotomy and regeneration alters the neurochemical phenotype of sensory neurons}

Nerve injury was also found to induce modest neurochemical changes in sensory neurons documented by an increase in total number of IB4-positive neurons and an increase in neurons that colabeled for both IB4 and TRPV1 in the DRGs. It is possible that the observed changes in cutaneous expression of neurotrophic factors after axotomy and regeneration are also associated with the observed changes in afferent neurochemical phenotype. The most prevalent cell type seen in the DRGs of naive mice is the CPM that stains positively for IB4 but not TRPV1. In naive mice, TRPV1 is found only in the small group of modality-specific (heat), GFR $\alpha 3$-positive (Fig. 2) cutaneous $\mathrm{CH}$ fibers that do not bind IB4 (Lawson et al., 2008). However, some CHs and CPMs were found to colabel for both TRPV1 and IB4 after regeneration. The increase in double labeling is most likely attributable to the observed increase in the incidence of IB4 binding in DRGs 4-10 weeks after axotomy and regeneration because the number of TRPV1-positive cells does not appear to be altered. These results also suggest the possibility that some of the artemin-responsive $\mathrm{CH}$ fibers may gain mechanical sensitivity after regeneration.

The apparent increase in IB4 binding contrasts with recent data describing a decrease in the number of IB4-positive cells after axotomy (Bennett et al., 2006). This study, however, axotomized and ligated the nerve in a manner that did not allow the nerve to regenerate to its target. Additionally, treatment of axotomized neurons with artemin (Bennett et al., 2006) or GDNF (Bennett et al., 1998) prevents any decrease in IB4 binding. We have shown that, immediately after axotomy, there is a significant increase in artemin and GDNF expression in the cutaneous target and an increase in their respective receptors in the DRG. Because the regenerating saphenous nerve reinnervates an artemin- and
GDNF-rich region, it is reasonable to suggest that the increase in IB4 binding after regeneration may be attributable to enhanced target-derived neurotrophic factor signaling.

\section{Clinical relevance}

We have reported recently that there are interesting similarities between the $\mathrm{CH}$ fibers found in the mouse (Lawson et al., 2008) and nonhuman primates (Baumann et al., 1991) and the mechanically insensitive C-fibers found in humans (Schmidt et al., 1995). The data presented here suggest that some silent nociceptors are activated after injury and become responsive to heat and that some $\mathrm{CH}$ neurons gain mechanical sensitivity. Both of these phenomena may be related to the observed increases in targetderived neurotrophic factor signaling after axotomy. Interestingly, similar findings have been reported in human studies. Ørstavik et al. (2003) found in patients with erythromelalgia that afferents with the biophysical properties of mechanically insensitive fibers (MIA) appeared to gain mechanical sensitivity. In addition, in a study of patients with diabetic neuropathy, Ørstavik et al. (2006) found that the percentage of MIA fibers with similar biophysical properties almost doubled compared with healthy controls. Together, these findings suggest a potential role for altered neurotrophic factor signaling on primary afferent sensitization in neuropathic pain states.

\section{References}

Albers KM, Woodbury CJ, Ritter AM, Davis BM, Koerber HR (2006) Glial cell-line-derived neurotrophic factor expression in skin alters the mechanical sensitivity of cutaneous nociceptors. J Neurosci 26:2981-2990.

Amir R, Michaelis M, Devor M (1999) Membrane potential oscillations in dorsal root ganglion neurons: role in normal electrogenesis and neuropathic pain. J Neurosci 19:8589-8596.

Baumann TK, Simone DA, Shain CN, LaMotte RH (1991) Neurogenic hyperalgesia: the search for the primary cutaneous afferent fibers that contribute to capsaicin-induced pain and hyperalgesia. J Neurophysiol 66:212-227.

Bender FL, Mederos Y, Schnitzler M, Li Y, Ji A, Weihe E, Guadermann T, Schäfer MK (2005) The temperature-sensitive ion channel TRPV2 is endogenously expressed and functional in the primary sensory cell line F-11. Cell Physiol Biochem 15:183-194.

Bennett DL, Michael GJ, Ramachandran N, Munson JB, Averill S, Yan Q, McMahon SB, Priestly JV (1998) A distinct subgroup of small DRG cells express GDNFF receptor components and GDNF is protective for these neurons after nerve injury. J Neurosci 18:3059-3072.

Bennett DL, Boucher TJ, Michael GJ, Popat RJ, Malcangio M, Averill SA, Poulsen KT, Priestley JV, Shelton DL, McMahon SB (2006) Artemin has potent neurotrophic actions on injured C-fibres. J Peripher Nerv Syst 11:330-345.

Bisby MA, Keen P (1986) Regeneration of primary afferent neurons containing substance P-like immunoreactivity. Brain Res 365:85-95.

Bradbury EJ, Burnstock G, McMahon SB (1998) The expression of P2X3 purinoreceptors in sensory neurons: effects of axotomy and glial-derived neurotrophic factor. Mol Cell Neurosci 12:256-268.

Campana WM, Li X, Dragojlovic N, Janes J, Gaultier A, Gonias SL (2006) The low-density lipoprotein receptor-related protein is a pro-survival receptor in Schwann cells: possible implications in peripheral nerve injury. J Neurosci 26:11197-11207.

Campbell JN (2001) Nerve lesions and the generation of pain. Muscle Nerve 24:1261-1273.

Carter DA, Lisney SJ (1987) The numbers of unmyelinated and myelinated axons in normal and regenerated rat saphenous nerves. J Neurol Sci 80:163-171.

Christianson JA, McIlwrath SL, Koerber HR, Davis BM (2006) Transient receptor potential vanilloid 1 -immunopositive neurons in the mouse are more prevalent within colon afferents compared to skin and muscle afferents. Neuroscience 140:247-257.

Chung MK, Lee H, Caterina MJ (2003) Warm temperatures activate TRPV4 in mouse 308 keratinocytes. J Biol Chem 278:32037-32046.

Chung MK, Lee H, Mizuno A, Suzuki M, Caterina MJ (2004) TRPV3 and 
TRPV4 mediate warmth-evoked currents in primary mouse keratinocytes. J Biol Chem 279:21569-21575.

Decosterd I, Ji RR, Abdi S, Tate S, Woolf CJ (2002) The pattern of expression of the voltage-gated sodium channels $\mathrm{Na}(\mathrm{v}) 1.8$ and $\mathrm{Na}(\mathrm{v}) 1.9$ does not change in uninjured primary sensory neurons in experimental neuropathic pain models. Pain 96:269-277.

Djouhri L, Koutsikou S, Fang X, McMullan S, Lawson SN (2006) Spontaneous pain, both neuropathic and inflammatory, is related to frequency of spontaneous firing in intact C-fiber nociceptors. J Neurosci 26:1281-1292.

Donnerer J, Liebmann I, Schicho R (2005) Differential regulation of 3-betahydroxysteroid dehydrogenase and vanilloid receptor TRPV1 mRNA in sensory neurons by capsaicin and NGF. Pharmacology 73:97-101.

Elitt CM, McIlwrath SL, Lawson JJ, Malin SA, Molliver DC, Cornuet PK, Koerber HR, Davis BM, Albers KM (2006) Artemin overexpression in skin enhances expression of TRPV1 and TRPA1 in cutaneous sensory neurons and leads to behavioral sensitivity to heat and cold. J Neurosci 26:8578-8587.

Fukuoka T, Tokunaga A, Tachibana T, Dai Y, Yamanaka H, Noguchi K (2002) VR1, but not P2X(3) increases in the spared L4 DRG in rats with L5 spinal nerve ligation. Pain 99:111-120.

Funakoshi K, Nakano M, Atobe Y, Goris RC, Kadota T, Yazama F (2006) Differential development of TRPV1-expressing sensory nerves in peripheral organs. Cell Tissue Res 323:27-41.

Gerevich Z, Borvendeg SJ, Schröder W, Franke H, Wirkner K, Nörenberg W, Fürst S, Gillen C, Illes P (2004) Inhibition of N-type voltage-activated calcium channels in rat dorsal root ganglion neurons by $\mathrm{P} 2 \mathrm{Y}$ receptors is a possible mechanism of ADP-induced analgesia. J Neurosci 24:797-807.

Höke A, Redett R, Hameed H, Jari R, Zhou C, Li ZB, Griffin JW, Brushart TM (2006) Schwann cells express motor and sensory phenotypes that regulate axon regeneration. J Neurosci 26:9646-9655.

Honore P, Kage K, Mikusa J, Watt AT, Johnston JF, Wyatt JR, Faltynek CR, Jarvis MF, Lynch K (2002) Analgesic profile of intrathecal P2X(3) antisense oligonucleotide treatment in chronic inflammatory and neuropathic pain states in rats. Pain 99:11-19.

Horch KW, Lisney SJ (1981) On the number and nature of regenerating myelinated axons after lesions of cutaneous nerves in the cat. J Physiol 313:275-286.

Hudson LJ, Bevan S, Wotherspoon G, Gentry C, Fox A, Winter J (2001) VR1 protein expression increases in undamaged DRG neurons after partial nerve injury. Eur J Neurosci 13:2105-2114.

Ishikawa K, Tanaka M, Black JA, Waxman SG (1999) Changes in expression of voltage-gated potassium channels in dorsal root ganglion neurons following axotomy. Muscle Nerve 22:502-507.

Jankowski MP, McIlwrath SL, Jing X, Cornuet PK, Salerno KM, Koerber HR, Albers KM (2008) Sox-11 transcription factor modulates peripheral nerve regeneration in adult mice. Brain Res. Advance online publication. Retrieved January 22, 2009. doi:10.1016/j.brainres.2008.12.032.

Kajander KC, Bennett GJ (1992) Onset of a painful peripheral neuropathy in rat: a partial and differential deafferentation and spontaneous discharge in A beta and A delta primary afferent neurons. J Neurophysiol 68:734-744.

Kim DS, Yoon CH, Lee SJ, Park SY, Yoo HJ, Cho HJ (2001) Changes in voltage-gated calcium channel alpha(1) gene expression in rat dorsal root ganglia following peripheral nerve injury. Brain Res Mol Brain Res 96:151-156.

Koerber HR, Woodbury CJ (2002) Comprehensive phenotyping of sensory neurons using an ex vivo somatosensory system. Physiol Behav 77:589-594.

Koerber HR, Druzinsky RE, Mendell LM (1988) Properties of somata of spinal dorsal root ganglion cells differ according to peripheral receptor innervated. J Neurophysiol 60:1584-1596.

Koerber HR, Mirnics K, Brown PB, Mendell LM (1994) Central sprouting and functional plasticity of regenerated primary afferents. J Neurosci 14:3655-3671.

Koerber HR, Mirnics K, Kavookjian AM, Light AR (1999) Ultrastructural analysis of ectopic synaptic boutons arising from peripherally regenerated primary afferent fibers. J Neurophysiol 81:1636-1644.

Koltzenburg M, Stucky CL, Lewin GR (1997) Receptive properties of mouse sensory neurons innervating hairy skin. J Neurophysiol 78:1841-1850.

Kress M, Koltzenburg M, Reeh PW, Handwerker HO (1992) Responsive- ness and functional attributes of electrically localized terminals of cutaneous C-fibers in vivo and in vitro. J Neurophysiol 68:581-595.

Küry P, Stoll G, Müller HW (2001) Molecular mechanisms of cellular interactions in peripheral nerve regeneration. Curr Opin Neurol 14:635-639.

Lawson JJ, McIlwrath SL, Woodbury CJ, Davis BM, Koerber HR (2008) TRPV1 unlike TRPV2 is restricted to a subset of mechanically insensitive cutaneous nociceptors responding to heat. J Pain 9:298-308.

Lee P, Zhuo H, Helke CJ (2001) Axotomy alters neurotrophin and neurotrophin receptor mRNAs in the vagus nerve and nodose ganglion of the rat. Brain Res Mol Brain Res 87:31-41.

Leitner ML, Molliver DC, Osborne PA, Vejsada R, Golden JP, Lampe PA, Kato AC, Milbrandt J, Johnson EM Jr (1999) Analysis of the retrograde transport of glial cell line-derived neurotrophic factor (GDNF), neurturin, and persephin suggests that in vivo signaling for the GDNF family is GFR $\alpha$ coreceptor-specific. J Neurosci 19:9322-9331.

Lisney SJ (1987) Functional aspects of the regeneration of unmyelinated axons in the rat saphenous nerve. J Neurol Sci 80:289-298.

Lundborg G, Dahlin L, Danielsen N, Zhao Q (1994) Trophism, tropism, and specificity in nerve regeneration. J Reconstr Microsurg 10:345-354.

Malin SA, Molliver DC, Koerber HR, Cornuet P, Frye R, Albers KM, Davis BM (2006) Glial cell line-derived neurotrophic factor family members sensitize nociceptors in vitro and produce thermal hyperalgesia in vivo. J Neurosci 26:8588-8599.

Mcllwrath SL, Lawson JJ, Anderson CE, Albers KM, Koerber HR (2007) Overexpression of neurotrophin-3 enhances the mechanical response properties of slowly adapting type 1 afferents and myelinated nociceptors. Eur J Neurosci 26:1801-1812.

Mearow KM, Kril Y, Diamond J (1993) Increased NGF mRNA expression in denervated rat skin. Neuroreport 4:351-354.

Mogil JS, Breese NM, Witty MF, Ritchie J, Rainville ML, Ase A, Abbadi N, Stucky CL, Séguéla P (2005) Transgenic expression of a dominantnegative ASIC3 subunit leads to increased sensitivity to mechanical and inflammatory stimuli. J Neurosci 25:9893-9901.

Molliver DC, Wright DE, Leitner ML, Parsadanian AS, Doster K, Wen D, Yan Q, Snider WD (1997) IB4-binding DRG neurons switch from NGF to GDNF dependence in early postnatal life. Neuron 19:849-861.

Oaklander AL, Brown JM (2004) Unilateral nerve injury produces bilateral loss of distal innervation. Ann Neurol 55:639-644.

Obata K, Noguchi K (2004) MAPK activation in nociceptive neurons and pain hypersensitivity. Life Sci 74:2643-2653.

Obata K, Yamanaka H, Fukuoka T, Yi D, Tokunaga A, Hashimoto N, Yoshikawa H, Noguchi K (2003) Contribution of injured and uninjured dorsal root ganglion neurons to pain behavior and the changes in gene expression following chronic constriction injury of the sciatic nerve in rats. Pain 101:65-77.

Orozco OE, Walus L, Sah DW, Pepinsky RB, Sanicola M (2001) GFRalpha3 is expressed predominantly in nociceptive sensory neurons. Eur J Neurosci 13:2177-2182.

Ørstavik K, Weidner C, Schmidt R, Schmelz M, Hilliges M, Jørum E, Handwerker H, Torebjörk E (2003) Pathological C-fibres in patients with a chronic painful condition. Brain 126:567-578.

Ørstavik K, Namer B, Schmidt R, Schmelz M, Hilliges M, Weidner C, Carr RW, Handwerker H, Jørum E, Torebjörk HE (2006) Abnormal function of C-fibers in patients with diabetic neuropathy. J Neurosci 26:11287-11294.

Peier AM, Reeve AJ, Andersson DA, Moqrich A, Earley TJ, Hergarden AC, Story GM, Colley S, Hogenesch JB, McIntyre P, Bevan S, Patapoutian A (2002) A heat-sensitive TRP channel expressed in keratinocytes. Science 296:2046-2049.

Price TJ, Flores CM (2007) Critical evaluation of the colocalization between calcitonin gene-related peptide, substance $\mathrm{P}$, transient receptor potential vanilloid subfamily type 1 immunoreactivities and isolectin $B 4$ binding in primary afferent neurons of the rat and mouse. J Pain 8:263-272.

Priestley JV, Michael GJ, Averill S, Liu M, Willmott N (2002) Regulation of nociceptive neurons by nerve growth factor and glial cell line derived neurotrophic factor. Can J Physiol Pharmacol 80:495-505.

Rau KK, Jiang N, Johnson RD, Cooper BY (2007) Heat sensitization in skin and muscle nociceptors expressing distinct combinations of TRPV1 and TRPV2 protein. J Neurophysiol 97:2651-2662.

Ruan HZ, Burnstock G (2003) Localisation of P2Y1 and P2Y4 receptors in dorsal root, nodose and trigeminal ganglia of the rat. Histochem Cell Biol 120:415-426. 
Ruocco I, Cuello AC, Ribeiro-Da-Silva A (2000) Peripheral nerve injury leads to the establishment of a novel pattern of sympathetic fibre innervation in the rat skin. J Comp Neurol 422:287-296.

Schmidt R, Schmelz M, Forster C, Ringkamp M, Torebjörk E, Handwerker H (1995) Novel classes of responsive and unresponsive C nociceptors in human skin. J Neurosci 15:333-341.

Shimizu I, Iida T, Guan Y, Zhao C, Raja SN, Jarvis MF, Cockayne DA, Caterina MJ (2005) Enhanced thermal avoidance in mice lacking the ATP receptor P2X3. Pain 116:96-108.

Sluka KA, Radhakrishnan R, Benson CJ, Eshcol JO, Price MP, Babinski K, Audette KM, Yeomans DC, Wilson SP (2007) ASIC3 in muscle mediates mechanical, but not heat hyperalgesia associated with muscle inflammation. Pain 129:102-112.

Smith DS, Skene JH (1997) A transcription-dependent switch controls competence of adult neurons for distinct modes of axon growth. J Neurosci 17:646-658

Snider WD, McMahon SB (1998) Tackling pain at the source: new ideas about nociceptors. Neuron 20:629-632.

Souslova V, Cesare P, Ding Y, Akopian AN, Stanfa L, Suzuki R, Carpenter K, Dickenson A, Boyce S, Hill R, Nebenuis-Oosthuizen D, Smith AJ, Kidd EJ, Wood JN (2000) Warm-coding deficits and aberrant inflammatory pain in mice lacking P2X3 receptors. Nature 407:1015-1017.

Taniuchi M, Clark HB, Johnson EM Jr (1986) Induction of nerve growth factor receptor in Schwann cells after axotomy. Proc Natl Acad Sci U S A 83:4094-4098.

Terenghi G (1995) Peripheral nerve injury and regeneration. Histol Histopathol 10:709-718.

Tominaga M, Caterina MJ (2004) Thermosensation and pain. J Neurobiol 61:3-12.

Wall PD, Devor M (1983) Sensory afferent impulses originate from dorsal root ganglia as well as from the periphery in normal and nerve injured rats. Pain 17:321-339.

Wang R, Guo W, Ossipov MH, Vanderah TW, Porreca F, Lai J (2003) Glial cell line-derived neurotrophic factor normalizes neurochemical changes in injured dorsal root ganglion neurons and prevents the expression of experimental neuropathic pain. Neuroscience 121:815-824.

Waxman SG (1999) The molecular pathophysiology of pain: abnormal expression of sodium channel genes and its contributions to hyperexcitability of primary sensory neurons. Pain [Suppl] 6:S133-S140.

Woodbury CJ, Ritter AM, Koerber HR (2001) Central anatomy of individual rapidly adapting low-threshold mechanoreceptors innervating the "hairy" skin of newborn mice: early maturation of hair follicle afferents. J Comp Neurol 436:304-323.

Woodbury CJ, Zwick M, Wang S, Lawson JJ, Caterina MJ, Koltzenburg M, Albers KM, Koerber HR, Davis BM (2004) Nociceptors lacking TRPV1 and TRPV2 have normal heat responses. J Neurosci 24:6410-6415

Wright DE, Snider WD (1995) Neurotrophin receptor mRNA expression defines distinct populations of neurons in rat dorsal root ganglia. J Comp Neurol 351:329-338.

Xiao HS, Huang QH, Zhang FX, Bao L, Lu YJ, Guo C, Yang L, Huang WJ, Fu G, Xu SH, Cheng XP, Yan Q, Zhu ZD, Zhang X, Chen Z, Han ZG, Zhang $\mathrm{X}$ (2002) Identification of gene expression profile of dorsal root ganglion in the rat peripheral axotomy model of neuropathic pain. Proc Natl Acad Sci U S A 99:8360-8365.

Xie Y, Zhang J, Petersen M, LaMotte RH (1995) Functional changes in dorsal root ganglion cells after chronic nerve constriction in the rat. J Neurophysiol 73:1811-1820

Xue Q, Jong B, Chen T, Schumacher MA (2007) Transcription of rat TRPV1 utilizes a dual promoter system that is positively regulated by nerve growth factor. J Neurochem 101:212-222.

Zwick M, Davis BM, Woodbury CJ, Burkett JN, Koerber HR, Simpson JF Albers KM (2002) Glial cell line-derived neurotrophic factor is a survival factor for isolectin B4-positive, but not vanilloid receptor 1-positive, neurons in the mouse. J Neurosci 22:4057-4065. 